Zagadnienia Rodzajów Literackich, LXII, z. 1

PL ISSN 0084-4446

DOI: https://doi.org/10.26485/ZRL/2019/62.1/11

\title{
Język i działanie w tradycji protestanckiej
}

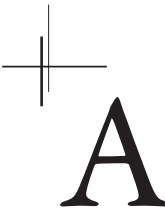

rtykuł jest interdyscyplinarną próbą nakreślenia głównych rysów protestanckiej perspektywy na Słowo i relacje między językiem a działaniem. Mieści się w ramach Nauk o kulturze i religii oraz teologii protestanckiej i jej historii. Ramą zasadniczą jest historia kultury, głównie kulturowa historia, w której główną rolę odgrywają przemiany nowoczesności: „odczarowanie świata”, „racjonalizacja” oraz filozofia krytyczna. Autorzy śledzą wątki „teologii słowa” i „teologii ucieleśnienia” oraz znajdują oryginalne konteksty w historii piśmienności oraz kultury „postpiśmiennej”. Wskazują na związek między słowem i działaniem oraz edukacją. Koncepcje protestanckie wpisują się, co prawda, w tradycje hebrajskiej syntezy modlitwy i badania, czyli czytania pisma, ale także w kulturową historię nowoczesności, której kamienie milowe można widzieć w wynalazku druku, dominacji kultury druku i pisma alfabetycznego oraz zapanowaniu przemysłu kulturalnego opartego na mediach audiowizualnych (wprowadzenie w problematykę można także znaleźć w: Pasek 2014, 19-28.).

Ewangelicyzm czy, szerzej ujmując zjawisko, protestantyzm, jak żaden dotąd nurt w chrześcijaństwie, położył szczególny akcent na słowo. Obraz czy inne formy doświadczania sacrum zostały w tej tradycji zepchnięte gdzieś daleko na drugi plan. Z lektury Biblii, czyli Słowa Bożego wyrosło przekonanie, że Bóg przemawia do człowieka właśnie za pośrednictwem tego medium. Komunikowanie się Stwórcy ze stworzeniem poprzez przyrodę zostało także odrzucone jako pozbawione precyzji, niepewne i subiektywne w oglądzie stąd już był tylko jeden krok do formuły sola scriptura, nazwanej przez Augusta Twestena (1789-1876) formalną zasadą protestantyzmu w odróżnieniu od zasady sola gratia et fide per Christum - ujmującej materialne zasady protestanckiej doktryny wiary. Owe redukcjonistyczne, łacińskie formuły sola - 'tylko, jedynie, wyłącznie' — z czasem zostały nazwane reformacyjnymi zasadami albo pryncypiami teologii ewangelickiej.

Na gruncie pneumatologii została później sformułowana zasada solum verbum, która głosi, że Bóg działa względem człowieka jedynie poprzez środki łaski (Uglorz 1995, 93), jakimi 
są Słowo Boże i sakramenty (chrzest oraz komunia święta) pojmowane jako verbum visibile. Tym samym dla tradycji protestanckiej znaczenie Słowa, a także i słowa, jest nie do przecenienia. Słowo ma moc zbawczą, a zarazem wzywa do działania.

Aby sformułować choćby w dużym uproszczeniu protestancki ogląd „słowa”, w rozumieniu „książkowym” jako „wypowiadanie się ustne lub pisemne, wypowiedź ustna lub pisemna, mowa, język” (WSJP 434-436), trzeba najpierw stwierdzić, że między protestancką tradycją refleksji o słowie a filologią od zarania istniały ścisłe więzi. Wprost można sformułować tezę, że Reformacja to radykalna filologia, jeśli filologię rozumieć etymologicznie jako „miłość słowa”, „umiłowanie słowa” (choć przecież także miłość nauki, książek, liter w średniowieczu, zaś w antyku także miłość rozmowy, dialogu, rozprawiania i uczoności). Zawołanie reformacyjne Lutra i jego naśladowców sola scriptura jest wezwaniem „z powrotem do Pisma Świętego”, „tylko Pismo Święte”, co oznaczało, że właśnie Pismo miało być jedynym argumentem w dysputach teologicznych i sporach z nich wynikających. Rok 1520 to czas ogłoszenia przez Lutra tak zwanych 3 pism programowych. Szczególne znaczenie wśród nich ma krótki traktat $O$ wolności chrześcijańskiej. To w nim odnajdujemy pierwszy na gruncie ewangelicyzmu program etyki jako wezwania do chrześcijańskiego zaangażowania w świecie. Luter pisze tam: „Chrześcijanin jest wolnym panem względem wszystkiego (wszystkich spraw) i nikomu niepodległym. Chrześcijanin jest najbardziej uległym sługą wszystkich (spraw) i każdemu podległym" (Luter 2009, 28). Luter jednoznacznie zrywa z uczynkowym pojmowaniem zbawienia i całej wiary chrześcijańskiej, co wyraża kolejne programowe zdanie z De libertate christiana: „Przez wiarę w Chrystusa nie jesteśmy wszak uwolnieni od uczynków, lecz od liczenia na uczynki, to znaczy od głupiego urojenia, że usprawiedliwienie zyskuje się przez uczynki”. Protestancki program zaangażowania wypływa z wiary. Człowiek Chrystusowy, będąc wyzwolony, jest zarazem wezwany do działania: wiara jest skuteczna poprzez miłość (fides per charitatem efficax) - głosiła odtąd ewangelicka etyka.

Zapierający się w swojej postawie na Sejmie Rzeszy w Wormacji w roku 1521 ks. dr Marcin Luter stwierdza „Tak oto stoję, inaczej nie mogę” i wzywa oponentów do przekonywania go przy pomocy Słowa, jedynie Słowa (Bainton 1950, 187).

Reformacyjne wystąpienie ks. dra Marcina Lutra miało w sobie głęboką troskę o Słowo pisane koniecznie z dużej litery. Był to zarazem, w jednym z najważniejszych elementów programu, protest wobec zafałszowywaniu prawdy Bożego Słowa. To właśnie na Sejmie w Wormacji, w szeroko pojętej przestrzeni publicznej, augustiański mnich, a zarazem profesor Uniwersytetu w Wittenberdze, oświadcza, że nie może odwołać swojej nauki, gdyż nie został przekonany argumentem Biblii bądź rozumowym. Nie może więc wyrzec się Prawdy. Tylko postawa księcia-elektora Fryderyka Mądrego, protektora Lutra, sprawiła, że ten w ukryciu jako wyjęty spod prawa cesarskiego, na zamku w Wartburgu, mógł całkowicie „oddać się Słowu” (Abromeit 2017, 109). Ten genialny badacz Słowa zaledwie w 16 tygodni przetłumaczył z greckiego oryginału na język niemiecki cały Nowy Testament. Za sprawą tego wiekopomnego tłumaczenia Słowo dotarło pod strzechy i stało się dla tysięcy, a po kilkudziesięciu latach już setek tysięcy ludzi nowym sposobem budowania relacji z Objawioną Prawdą. Nie do przeoczenia jest wykorzystanie przez obóz reformacyjny nowego medium, jakim był wówczas druk, wynaleziony i rozpowszechniony kilkadziesiąt lat wcześniej przez Jana Gutenberga (1400-1468). Często jest w tym kontekście przywoływana „teologia wcielenia”, czyli inkarnacji, która podkreśla za ewangelistą Janem: „Słowo ciałem się stało i zamieszkało wśród nas” (J 1,14). Luter w swych wykładach i kazaniach wielokrotnie komentował wiersze zapisane 
przez czwartego ewangelistę. Sam widział w Piśmie Świętym Starego i Nowego Testamentu nade wszystko viva vox evangelii, żywe Słowo ewangelii, któremu przeciwstawiał martwą literę Prawa.

Jedna z reformacyjnych zasad „sola” głosi, że jedyną drogą przekazu woli Boga jest Słowo - tylko słowo, nie przyroda i inne formy transmisji. Przywołana już zasada solum verbum oznacza, że Bóg zwraca się do człowieka wyłącznie poprzez Słowo, którego jedynym medium jest słowo. By do tego słowa spinanego człowiek mógł dotrzeć, niezbędna jest edukacja.

Stąd protestantyzm podjął walkę o powszechne kształcenie, o dostęp do edukacji, by w pierwszym rzędzie dać wszystkim możliwość osobistego obcowania ze Słowem. Od duchownego ewangelickiego wymagano przede wszystkim umiejętności egzegezowania Bożego Słowa, stąd obowiązek umiejętności lektury Biblii w językach oryginalnych po hebrajsku, aramejsku i grecku. Filip Melanchton (1497-1560), najbliższy współpracownik Lutra, właśnie za realizację programu powszechnej scholaryzacji został już przez potomnych określony mianem Praeceptor Germaniae, nauczyciel Niemiec, bo rzeczywiście rola Magistra Filipa, autora koncepcji szkoły humanistycznej, w tym przełomowym procesie jest nie do przecenienia. Warto dodać, że w samym akcie nauki Melanchton szczególną rolę przypisywał matematyce jako nauczycielce precyzyjnego myślenia. Wpisuje się to w kulturowy proces uwewnętrzniania logiki kultury druku.

Wspomniane już zawołanie do Biblii - czyli ad fontes, realizowane w protestanckiej odsłonie - stało się ekskluzywną zasadą protestantyzmu: sola scriptura, czyli — Boże Słowo zapisane jest wyłącznie w Piśmie Świętym. Przy tym dla teologii ewangelickiej Pismo Święte, czyli Biblia, ma charakter zarówno ludzki, jak i boski. Marcin Luter sformułował zasadę interpretacji całości życia chrześcijańskiego opartą wyłącznie (sola) na tekście Biblii — Pisma Świętego Starego i Nowego Testamentu, z czasem uzupełnił to zasadą samotłumaczenia się Biblii (sui ipsius interpres) (Bronk 2002).

Oznacza to, że każde zdanie Biblii ma w sobie przekaz natchniony i stanowi medium objawienia, a zarazem traktowane jest jako dzieło człowieka powstałe w określonym kontekście społeczno-kulturowym. Tak ujęła to ostatecznie kilka wieków później teologia egzystencjalna, sformułowana expressis verbis przez Rudolfa Bultmanna (1884-1976). Konsekwencją skryptocentryzmu było stworzenie nowych zasad organizacji ewangelickiego nabożeństwa. Wraz z odrzuceniem ofiarnego charakteru komunii świętej przeorientowano przekaz kultu Bożego (Gottesdienst). Centralne miejsce w ewangelickim nabożeństwie zajmuje kazanie, czyli głoszenie Słowa Bożego, aktualizacja biblijnego przesłania, gdzie tekst spotyka się z kontekstem. Nawet sakrament ołtarza, czyli komunia święta, rozumiany jest jako widzialna postać Słowa, czyli obecność Chrystusa w darach, i stanowi zwiastowanie odpuszczenia grzechów. Duchowny przestaje być pojmowany jako kapłan sprawujący ofiarę, lecz jest nade wszystko minister verbi divini - sługą Słowa Bożego. Jest to kaznodzieja, predykant (od Predigt — kazanie), duszpasterz i katecheta przekazujący w różnej formie orędzie Słowa: naukę o usprawiedliwieniu z łaski przez wiarę. Ewangelicki ksiądz to także ojciec rodziny, a plebania staje się pastorskim domem (Abromeit 2017, 111). Droga do stanu duchownego wiedzie przez studia teologiczne, w tym także obowiązkowo przez studium języków klasycznych, które dają zestaw narzędzi niezbędnych do samodzielnej interpretacji Pisma, nazywanej egzegezą biblijną, a w szerszym ujęciu określonej mianem hermeneutyki.

Warto wspomnieć, że samo pojęcie hermeneutyki pojawiło się po raz pierwszy właśnie w protestanckim świecie naukowym. W programowym dziele teologa okresu ortodoksji 
luterańskiej, Johanna Conrada Dannhauera (1603-1666) - Hermeneutica sacra sive methodus exponendarum sacrarum litterarum $\mathrm{z}$ roku 1654, po raz pierwszy w literaturze naukowej w tytule dzieła został zastosowany termin hermeneutyka. Strasburski teolog jest uważany wprost za ojca nowożytnej hermeneutyki (Bautz 1990), a to za sprawą programowej pracy $\mathrm{z}$ roku 1630 - Idea boni interpretis et malitiosi calumniatoris. Hermeneutyka, w rozumieniu Dannhauera, to całościowa sztuka rozumienia, ujęta jako relacja do tekstu, do słowa, nie tylko Słowa Bożego. Było to pierwsze ujęcie hermeneutyki jako metody naukowej w znaczeniu ogólnym, a nie tylko, jak w dotychczasowej wąskiej praktyce, jedynie w kontekście biblijnym lub prawniczym (Bosse 1898).

Można zatem śmiało powiedzieć: Reformacja jest radykalną filologią. Jednak, co za tym idzie, jest to filologia, która wedle XX-wiecznych kryteriów w pełni staje się logocentryzmem, choć francuski filozof, wywodzący się z judaizmu Jacques Derrida (1930-2004), zapewne nie miał intencji wiązania logocentryzmu wyłącznie z filologią. Wcześniej twórca słowa „logocentryzm”, niemiecki filozof, radykalny krytyk ideologii postępu, Ludwig Klages (18721956), w latach 20. XX wieku także odnosił logocentryzm do całej tradycji zachodniej nauki i filozofii, która widziała w języku i słowach wyraz zewnętrznej rzeczywistości (Preußer 1999). Sam Derrida widział logocentryzm najpierw w idei Ferdinanda de Saussaure’a (1857-1913), który przypisywał dźwiękowość słowu pisanemu, zaś potem rozciągnął on tę jakość na całą kulturę Zachodu, której fundamentem miała być „metafizyka obecności”.

Logocentryczny i filologiczny wymiar Reformacji bywa czasami aż bardzo dosłowny, za co odpowiada protestancki fundamentalizm religijny. Po raz pierwszy owo dosłowne, literalne odczytanie Biblii znajdujemy już w pewnych wątkach myśli Reformatora, wyraźnie w podręcznikach dogmatyki ortodoksji luterańskiej, następnie w ruchu pietystycznym zapoczątkowanym przez Filipa Spenera (1635-1705) i w jego programowym dziele z roku 1675 zatytułowanym Pia desideria, czyli Pobożne życzenia (Spener 2002). Jednym z postulatów Spenera zawartych w tym dziele jest szerokie wprowadzenie w praktykę kościelną tzw. godzin biblijnych (Bibelstunden), czyli spotkań, w ramach których wierni mają za zadanie wykładanie tekstów biblijnych.

Nurt fundamentalistyczny obecny jest w protestantyzmie cały czas. Trwale wpisał się w perspektywę myśli XX-wiecznej. Neopietyzm czy ewangelikalizm głosi, że należy wiernie, czyli fundamentalistycznie, odnieść się do Biblii, do słowa spisanego i wywodzi wiele zasad z literalnej interpretacji Biblii. Warto zaznaczyć, że ten literalizm jest tylko jednym z wcieleń protestantyzmów i to niedominującym. Tradycyjna teologia akademicka odrzuca ten sposób podejścia do Słowa, które nie jest martwe, lecz wciąż żywe. Słowo należy odczytywać nieustannie na nowo, każdorazowo dla kolejnej generacji, kolejnego pokolenia, które formułuje własne pytania. Szczególnie tę zależność widać w stosowanej przez głównego przedstawiciela teologii liberalnej XX wieku, Paula Tillicha (1886-1965), metodzie korelacji, w której to filozofia formułuje pytania, a teologia właśnie w przekazie zawartym w Piśmie Świętym powinna znaleźć odpowiedź (Łata 1995: 9).

Od razu też trzeba wprost powiedzieć, że Reformacja jako radykalna filologia, umiłowanie słowa, ale i wiedzy, przeciwstawiała się jednak magicznemu podejściu do słowa: słynne magiczne zawołanie „hokus-pokus” wywodzi się prawdopodobnie z początku XVII wieku i jest jarmarczną wersją łacińskiej formuły wypowiadanej podczas konsekracji: Hoc est corpus meum. „Hokus-pokus” to wyraz nadal używany jako zabawne zaklęcie, oznaczające zamianę czegoś w coś innego, mamienie innych osób lub niewytłumaczalne zjawisko. Jego etymologia 
bywa jednak różnorodnie wyjaśniana. Według słownika etymologicznego Friedricha Klugego, słowo to jest właśnie bluźnierczym przekształceniem formuły mszalnej: Hoc est corpus meum - ale już sam Kluge uważał to wyjaśnienie za mało prawdopodobne. Objaśnienie takie kwestionuje Eugeniusz Słuszkiewicz, według którego jest to formułka pseudołacińska. Od członu hocus pochodzi angielski wyraz hoax (mistyfikacja) (Hokus-pokus 2018; Hocus Pocus (magic) 2019; por. Słuszkiewicz 1970: 468 — w tej notatce Słuszkiewicz koryguje błędną, według niego, etymologię hasła u Doroszewskiego pod Focus-pokus).

Jednak pomimo odczarowania zaczarowanego świata i oderwania się od magicznych formuł relacja protestantyzmu pozostaje logocentryczna i uznająca moc słowa jako inspiracji. Jeremiaszowe „I rzekł do Jeremiasza Pan: Oto wkładam moje słowa w twoje usta” (Jr 1,9) może stanowić zalążek teorii zwiastowania słowa Bożego, które jest natchnione i przenosi owo natchnienie na słuchacza. W Ewangelii także znajdziemy potwierdzenie takiej optyki: „Weźcie więc to sobie do serca, by nie przygotowywać sobie naprzód obrony. Ja bowiem dam wam usta i mądrość” (Łk 21,14-15). Zatem natchnienie, które kojarzy się ze słowem, każe także myśleć o improwizacji jako gatunku mowy, który byłby szczególnie ewangeliczny i nadający się do reprezentacji Słowa w ewangelickim rozumieniu. Jednak proces, który Max Weber (1864-1920) nazwał odczarowaniem, jest także zjawiskiem nieuchronnym w świecie zachodniego chrześcijaństwa i w odniesieniu do słowa oznacza związek teologii słowa z hermeneutyką krytyczną, albo nawet ze sceptycyzmem hermeneutycznym, czyli dekonstrukcjonizmem. Odczarowanie świata, czyli odejście od magicznej jego koncepcji oraz swego rodzaju homogenizacja samej struktury światowej nieuchronnie kojarzy się z racjonalizacją i duchem kapitalizmu, ta zaś z dominacją liczby i liczenia, której znaczenie w edukacji tak bardzo podkreślał Melanchton. Zatem tak rozumiane słowo staje się w świecie odczarowanym liczbą, a w wersji radykalnie sceptycznej — różnią (differance), opóźnieniem, nieobecnością, by odwołać się raz jeszcze do Derridy.

Protestancka koncepcja słowa rodzi zatem bardzo różne koncepcje pochodne: fundamentalistyczną interpretację literalną słowa (i co za tym idzie bardzo zachowawcze wizje stworzenia świata), krytyczną hermeneutykę historyczną z odmianami hermeneutyki egzystencjalnej oraz radykalnie krytyczną sceptyczną wizję hermeneutyczną w postaci dekonstrukcjonizmu, który w istocie atakuje logocentryzm, ale jest to wciąż atak w ramach tego samego paradygmatu.

We wszystkich nurtach myślenia wywodzącego się z radykalnej filologii, czyli Reformacji, istotne jest przekonanie o ucieleśnieniu słowa. Owo ucieleśnienie w wersji literalnej jest tożsame z katolicką transsubstancjacją, jednak także w wersji fundamentalistycznej i umiarkowanie krytycznej, historycznej można znaleźć przekonanie o konieczności narodzenia się na nowo jako konsekwencji zetknięcia się z właściwie zwiastowanym słowem/Słowem. Słowo staje się ciałem, to znaczy, że w nawróceniu musi narodzić się nowy człowiek, nowy Adam, człowiek wewnętrzny. W protestantyzmie polskim zawsze ten doświadczeniowy charakter był widoczny w tym, że podkreślano doświadczeniowość i przeżyciowość prawdy, stąd w polskich kancjonałach protestanckich można znaleźć wyrażenie „szczyro prawda” (Kawecka-Gryczowa 1978). Motyw ten odnaleźć można u ojca języka polskiego, Mikołaja Reja z Nagłowic (1505-1569), który był także ewangelickim teologiem (Leszczyński 2005: 12). Najwyraźniej widoczna koncepcja ta jest w Psatterzu Jana Kochanowskiego (1530-1584), zwłaszcza w Psalmie XII: 
Pańskie słowa są czyste, i prózne przygany,

Pańskie słowa brant szczery, siedmkroć przelewany.

Panie, Ty nas zachowaj od ludzi zdradliwych,

Złych zewsząd pełno, kiedy władza jest złośliwych.

W innych miejscach także to odnajdziemy: „Te się na wieki żadnych lat nie boją, / Bo na szczyrości i na prawdzie stoją”, „Szczyra prawda Twe wyroki; wyrwi mię z rąk złemu”. Kochanowski nie był formalnie protestantem, jednak sprawa jego przynależności konfesyjnej jest bardzo złożona, kultura reformacji była w owym czasie znacznie szersza niż instytucjonalne przyporządkowania (zob. Płuciennik 2017).

Jednak z upływem czasu rozwój hermeneutyk biblijnych i świeckich doprowadził do krytycyzmu i historycyzmu, które pomimo ucieleśnienia słowa nakazywały podejrzliwość, nieufność względem oczywistości. Adam Mickiewicz, pozostający wedle Zdzisława Kępińskiego (1980) pod wpływem pietystów litewskich, napisał także:

Język kłamie głosowi, a głos myślom kłamie,

Myśl z duszy leci bystro, nim się w słowach złamie,

A słowa myśl pochłoną i tak drżą nad myślą,

Jak ziemia nad połkniętą, niewidzialną rzeką.

Z drżenia ziemi czyż ludzie głąb nurtów docieką,

Gdzie pędzi, czy się domyślą?

Na przełomie XIX i XX wieku tradycja radykalnej filologii przyczyniła się do narodzin radykalnego krytycyzmu, co zaowocowała myślą sceptyczną, a także mistycyzmem.

W tradycji protestanckiej pozostaje także zjawisko widoczne w szczególnie nacechowanym protestanckim rysem słowie „upamiętanie”. „Upamiętać się” zastąpiło ogólnopolskie „opamiętać się” i jest silnie związane z autokrytycznym spojrzeniem podmiotu religijnego, który nieufnie patrzy nie tyle na zewnątrz siebie, na świat, ile na siebie samego. „Narodzenie na nowo” to także spojrzenie na siebie i „upamiętanie się” (Mt 4,17), temu ma służyć kazanie, czyli głoszenie/zwiastowanie Słowa, które jak „miecz” potrafi działać w świecie.

Warto raz jeszcze podkreślić, że koncepcja słowa w protestantyzmie przyczyniała się przez wieki do krzewienia edukacji na wszystkich jej poziomach. To w tej tradycji intelektualnej narodziła się myśl o powszechnej ewangelizacji, a co za tym idzie — powszechnej edukacji. Takie postulaty znaleźć można już w XVI wieku, zaś Jan Amos Komensky (1592-1670), który sam studiował teologię w protestanckim Heidelbergu, stał się twórcą powszechnego systemu nauczania i autorem przełomowych podręczników szkolnych. Warto wskazać, że obowiązek szkolny znaleźć można już u Frycza-Modrzewskiego w jego fundamentalnym dziele De Republica Emendanda i przypomnieć należy, że takiemu obowiązkowi sprzeciwiał się wówczas Kościół rzymskokatolicki. W XIX wieku inspiracja do upowszechnienia edukacji wychodziła ze słynnych szkółek niedzielnych - nabożeństw dla dzieci paralelnych do nabożeństwa dla dorosłych, wtedy także powstał ruch socjalistycznych szkółek niedzielnych na wyspach brytyjskich. Można to uznać za zwieńczenie procesu widocznego już w wieku XVIII w koncepcji teologa i pedagoga Jana Juliuszu Heckera (1707-1768) i jego koncepcji szkoły realnej powstałej w 1747 roku w Berlinie. 
W tradycji biblijnej egzegezy protestanckiej mieści się także wydawanie tak zwanych poliglot — paralelnych tekstów wielojęzykowych: w XVII wieku poliglota londyńska miała aż dwanaście wersji językowych.

$\mathrm{Na}$ koniec warto wskazać, że radykalnie krytyczna koncepcja słowa protestanckiego mogła tak bardzo absolutyzować słowo Boże czy Słowa Jezusa, że wręcz znosi religijność: Dietrich Bonhoeffer (1906-1945) jest autorem koncepcji areligijnego chrześcijaństwa, które niesie z sobą radykalne rozumienie słowa jako działania w świecie; działania opartego na wolności. Nieobecność Boga w świecie niesie za sobą całkowitą odpowiedzialność człowieka za świat (Bonhoeffer 1992). Podobny motyw odnajdziemy również u Tillicha i jego filozoficzno-teologicznej koncepcji męstwa bycia (courage to be). Męstwo według niego to pojęcie ontologiczne, które jest "powszechną i istotną afirmacją danego bytu” (Tillich 1994: 162). Ma ono jednocześnie wymiar moralny: męstwo to „akt etyczny, w którym człowiek afirmuje własny byt wbrew tym elementom swego istnienia, które przeciwstawiają się podstawowej afirmacji człowieka" (Tillich 1994: 8). Zaangażowanie w słowo wymusza nieuchronnie odpowiedź, czyli zaangażowanie w świat, i odpowiedzialność — przynajmniej tak to jest w tradycji protestanckiej już od ponad 500 lat.

W ten sposób nakreślony zarys kultury słowa — radykalnej filologii, wynikającej z Reformacji, każe potwierdzić rozpoznania nienowe, obecne w ostatnim eseju książkowym Jacka Dukaja, który pisze m.in.: „Istotnie można więc uznać protestantyzm za nieunikniony efekt pełnej adaptacji do myślunku pisma. Gdy każdy sam czyta Biblię, relacja człowieka z Bogiem nie przypomina już sytuacji rozmowy, słuchania, spotkania z Mistrzem; jest krytyczną analizą upodmiotowionego słowa" (Dukaj 2019: 5098-5100).

Wydaje nam się, że sprawa jest jednak nieco bardziej złożona, protestantyzm w tym kontekście z jednej strony na pewno kontynuuje judaistyczną tradycję syntezy modlitwy i badania, to jest lektury Pisma. Widoczne staje się to także w tej dialektyce nowoczesnego „odczarowania” i krytycyzmu, ale także cielesności przeżycia - hermeneutycznego Erlebnis - Słowa/słowa). Z drugiej jednak strony, zjawisko widoczne u Bonhoeffera jest ewidentnym śladem głębokich przemian kulturowych wynikłych z historycznych okoliczności. Dukaj dalej pisze: „Jak wobec tego chrześcijaństwo przystosuje się do kultury postpiśmiennej? Czy w ogóle może istnieć poza słowem? «Na początku było Słowo» - i na końcu też jest słowo. A to znaczy: po słowie jest już coś innego, nie-chrześcijaństwo" (Dukaj 2019: 5110-5114). Wydaje nam się, że nie można pomijać w tym kontekście „areligijnego chrześcijaństwa” Bonhoeffera, także jako perspektywy kultury postpiśmiennej. Z drugiej strony, w protestanckiej koncepcji języka i działania ciągle będzie powracać sola scriptura, czyli z perspektywy nauk o kulturze i religii będzie to kontynuacja tej dialektyki "modlitwy i badania — czyli lektury” słowa, lektury Pisma. To samo w sobie nie musi oznaczać odwrotu i dominacji popularnej obecnie „duchowości” (ang. spirituality), często apodmiotowej i inspirowanej filozofiami oraz religijnością Wschodu. Jeśli Dukaj pisze:

Tak oto otwiera się nowa droga uprawiania filozofii: b y c i e. Największym filozofem epoki transferu przeżyć nie będzie autor głębokich rozpraw ani założyciel szkoły myślenia. (Nie będzie rozpraw; nie będzie szkół myślenia). Lecz ktoś, kto po prostu żył. W pewien określony, specyficzny, odkrywczy sposób. 
to musimy jeszcze raz wskazać na przykład Bonhoeffera, który właśnie w byciu znalazł pełne ucieleśnienie Słowa. „Odwaga bycia” Tillicha jest w tym kontekście nie tylko wnioskiem z wojennych i totalitarnych doświadczeń faszyzmu niemieckiego, ale także może stanowić inspirację dla nowej formy duchowości postpiśmiennej. Radykalna wizja rozwoju kultury, w której znikają poprzednie jej formy, jest nie do przyjęcia. Tym bardziej że w świetle kryzysu klimatycznego rozwój kultury coraz bardziej musi być także widziany w świetle kryzysu energetycznego - kryzysu energii jako takiej. Słowo tak czy owak pozostanie dla protestantów „warownym grodem”.

MARCIN HINTZ

https://orcid.org/0000-0001-7663-1085

Chrześcijańska Akademia Teologiczna w Warszawie

Wydział Teologiczny (Katedra Teologii Systematycznej)

m.hintz@chat.edu.pl

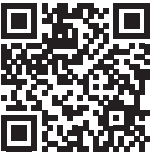

JAROSŁAW PŁUCIENNIK

(iD) https://orcid.org/0000-0001-6984-7734

Uniwersytet Łódzki Wydział Filologiczny

(Instytut Kultury Wspólczesnej, Katedra Teorii Literatury)

jaroslaw.pluciennik@uni.lodz.pl

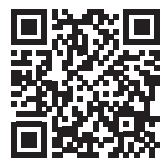




\section{Bibliografia}

Abromeit Hans-Jürgen (2017), The Luther Effect: What was the aim of the Reformer and what was the result?, „Gdański Rocznik Ewangelicki” Vol, X, s. 107-114.

Bainton Roland Herbert (1950), Here I stand. A life of Martin Luther, Abingdon Press, New York-Nashville.

Bautz Friedrich W. (1990), Dannhauer, Johann Konrad [w:] Biographisch-Bibliographisches Kirchenlexikon (BBKL), Traugott Bautz Verlag, s. 1211-1212.

Bonhoeffer Dietrich (1992), Ethik, hg. von Tödt I., Tödt H.-E., Feil E., Green C., Kaiser Verlag, München.

Bosse Friedrich (1898), Dannhauer, Johann Conrad [w:] Realencyklopädie für protestantische Theologie und Kirche (RE) 3. Auflage, Bd. 4, Leipzig, s. 460-464.

Bronk Andrzej (2002), Hermeneutyka [w:] Religia. Encyklopedia PWN, t. 4, Naukowe PWN, Warszawa.

Dukaj Jacek (2019), Po Piśmie, Wydawnictwo Literackie, Kraków.

Hocus Pocus (Magic) (2019), Wikipedia, 23 February, https://en.wikipedia.org/w/index.php?title=Hocus_pocus_(magic)\&oldid=884702723 [dostęp: 23.02.2019].

Hokus-pokus (2018), Wikipedia, 20 października. https://pl.wikipedia.org/w/index.php?title=Hokus-pokus\&oldid=54783492 [dostęp: 23.02.2019].

Kawecka-Gryczowa Alodia (1978), Spory o „szczyra prawdę”, „Odrodzenie i Reformacja w Polsce", XXIII, s. 227-232.

Kochanowski Jan (1579), Psatterz Dawidów przektadania Jana Kochanowskiego, w Drukarni Łazarzowej, Kraków.

Kępiński Zdzisław (1980), Mickiewicz hermetyczny, PWN, Warszawa.

Leszczyński Rafał (sen.) (2005), Mikotaj Rej (1505-1569). Wielki ewangelik, szermierz „szczyrego Stowa Bożego”, "Jednota” 79/1-2, s. 12.

Luter Marcin (2009), Pisma etyczne, red. Hintz M., Wydawnictwo Augustana, Bielsko-Biała.

Łata Jan A. (1995), Odpowiadająca teologia Paula Tillicha, Oficyna Wydawnicza Signum, Oleśnica.

Pasek Zbigniew (2014), Protestancka kultura stowa [w:] Kultura religijna protestantyzmu, Wydawnictwo Libron-Filip Lohner, Kraków.

Płuciennik Jarosław (2017), Dyskurs reformacyjny w parafrazie Psalmu 110 Jana Kochanowskiego [w:] Spadkobiercy Reformacji. Ewangelicy w Lublinie i na Lubelszczyźnie (Historia, kultura, ekonomia, literatura) / Erben der Reformation Protestanten in Lublin und Lubliner Land (Geschichte. Kultur. Wirtschaft. Literatur), red. Brudny G., Matwiejczyk W., Willaume M., Żurek S. J., Towarzystwo Naukowe KUL, Lublin, s. 343-56, http://dspace.uni.lodz. $\mathrm{pl}: 8080 /$ xmlui/handle/11089/24086 [dostęp: 15.01.2019].

Preußer Heinz-Peter (1999), Logozentrismus und Sinn Indikatoren eines Paradigmenwechsels Ludwig Klages - Jacques Derrida - George Steiner, „Weimarer Beiträge, Zeitschrift für Literaturwissenschaft, Ästhetik und Kulturwissenschaften” 45. Jg. /2, s. 199-217.

Słuszkiewicz Eugeniusz (1970), Hokus-pokus, „Poradnik Językowy” 7, https://poradnik-jezykowy.uw.edu.pl/issue/827 [dostęp: 23.02.2019].

Spener Filip J. (2002), Pia desideria, przeł. M. Platajs, Wydawnictwo Augustana, Bielsko-Biała. Tillich Paul (1994), Męstwo bycia, przeł. H. Bednarek, Rebis, Poznań. 
Uglorz Manfred (1995), Od samoświadomości do świadectwa wiary. Wprowadzenie do dogmatyki ewangelickiej, Chrześcijańska Akademia Teologiczna, Warszawa.

WSJP - Wielki Stownik Jezyka Polskiego, PWN, Warszawa, https://wsjp.pl/index.php?pwh=0 [dostęp: 15.01.2019].

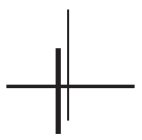

